\title{
Seasonal variation of the qualitative and quantitative composition of triterpenic compounds and antioxidant activity in vitro in the apple extracts of cultivars grown in Lithuania
}

\section{A. Butkevičiūtè ${ }^{1 *}$, \\ R. Urbštaite் ${ }^{1}$, \\ M. Liaudanskas ${ }^{1,2}$, \\ D. Kviklys ${ }^{2}$,}

J. Viškelis ${ }^{2}$,

\section{Janulis ${ }^{1}$}

${ }^{1}$ Department of Pharmacognosy,

Faculty of Pharmacy,

Lithuanian University of Health Sciences,

13 Sukilèiu Street,

50162 Kaunas, Lithuania

${ }^{2}$ Institute of Horticulture,

Lithuanian Research Centre

for Agriculture and Forestry,

30 Kauno Street,

54333 Babtai,

Kaunas District, Lithuania
Apple (Malus domestica Borkh.) fruits are rich in phenolic glycosides, triterpenic acids and other biologically active compounds. The apples are widely used as food products due to their biologically active compounds that have specific biological effects. It is important to use high quality apples or their recycling products, so it is necessary to investigate the qualitative and quantitative composition of the bioactive compounds.

The amount of triterpenic acids varies during different phenological stages of apple development and maturation. In order to determine in which phenological stage of apple growth the quantity of triterpenic acids was highest, high-performance liquid chromatography was applied. The highest total amounts of triterpenic compounds were detected at the beginning of the phenological stage of fruit development. The study showed that the highest amounts of triterpenic acids were detected at the beginning of the phenological stage of apple development, while as the apple matured, the amount of triterpenic acids decreased from $2.63 \pm 0.26 \mathrm{mg} / \mathrm{g}$ to $1.6 \pm 0.28 \mathrm{mg} / \mathrm{g}$. In this study, we identified and quantified four triterpenic compounds, which by the quantitative composition of triterpenic acids could be arranged in the following ascending order: betulinic acid $<$ corosolic acid $<$ oleanolic acid $<$ ursolic acid.

In order to use herbal extracts for medical practice it is important to perform biological effects study in vitro and in vivo. Antioxidants with different mechanisms of action neutralize harmful reactive oxygen and nitrogen forms and enhance antioxidants protection systems. The antioxidant activity of apple extracts in vitro varied during different phenological stages of the fruit. The strongest antiradical and reductive activities were observed at the beginning of apple development. In order to determine the relationship between the antioxidant activity of the acetone extracts of apples assessed by DPPH, ABTS, CUPRAC and FRAP assays and the total amount of triterpenic acids in these extracts, a correlation analysis was carried out. The strongest positive correlation was observed between the amount of oleanolic acid and the antioxidant activity assessed by DPPH, ABTS and CUPRAC methods (respectively, $r=0.778, r=0.784$ and $r=0.720$ ).

Keywords: apple, antioxidant activity, triterpenic compounds

\footnotetext{
* Corresponding author. Email: Aurita.Butkeviciute@lsmu.lt
} 


\section{INTRODUCTION}

The apple is one of the most widely consumed fruit in the world [33]. The phytochemical composition of the apples depends on various environmental factors, such as the climatic conditions, geographical locations, soil, care technologies of trees, the time of picking and storage conditions $[19,24,28]$. The quality of the apples depends not only of the beginning of fruiting and the yield, but also on the rootstock and the cultivars of the apples [ [ 8]. The apples are an important part of human nutrition and are a source of various biologically active compounds [14]. Apples are rich in phenolic and triterpenic compounds, vitamins, micro- and macro-elements, fibers, amino acids, fatty acids and organic acids $[13,26,28$. The biological effects of triterpenic compounds found in plants of the genus Malus Mill. have been widely described [3]. The biological effects of triterpenic compounds are shown in Fig. 1. The apple extracts exhibited a strong antioxidant activity [20, 21]. The phenolic compounds act as natural antioxidants and bind free radicals, inhibit the products of their reactions, and stimulate the synthesis of antioxidant enzymes, which prevent oxidative stress-induced lipid damage to molecular structures of the body such as DNA [21]. The antioxidant mechanisms described in many studies have important implications for the protective effect of apple extracts not only against cancer, but also against cardiovascular disease, Alzheimer's disease, asthma and, potentially, diabetes [9].

The amount of biologically active compounds accumulated in plant organs varies depending on the phenological growth stage. Therefore, it is important to determine the variability in the com- position of triterpenic compounds in apple extracts and the antioxidant activity during different phenological stages of fruit development and maturation. The results of the research will ensure the development and production of nutritional supplements, functional food, or other products of apple extracts rich in triterpenic compounds.

The aim of the study was to determine the qualitative and quantitative composition of triterpenic compounds and their antioxidant activity in apple extracts during different phenological stages of fruit development and maturation.

\section{EXPERIMENTAL}

\section{Plant materials}

We studied fruit samples of the Connel Red and Ligol apple cultivars. The apple trees were grown in the experimental orchard of the Institute of Horticulture, the Lithuanian Research Centre for Agriculture and Forestry, Babtai, Lithuania $\left(55^{\circ} 60^{\prime} \mathrm{N}, 23^{\circ} 48^{\prime} \mathrm{E}\right)$. The apples were picked 10 times during the vegetation period, during different stages of fruit development and maturation (Table 1). The study was performed in 2017-2018.

\section{Chemicals}

All solvents, reagents and standards used were of analytical grade. Acetonitrile, acetone, acetic acid, ursolic acid, oleanolic acid, betulinic acid, corosolic acid and hydrochloric acid were obtained from Sigma-Aldrich GmbH (Buchs, Switzerland), and ethanol from Stumbras AB (Kaunas, Lithuania). ABTS (2,2'-azino-bis (3-ethylbenzothiazoline-6-sulfonic acid)), trolox (6-hydroxy-2,5,7,8-tetramethylchroman-2-carboxylic acid), potassium persulfate, copper (II) chloride, ammonium acetate, neocuproine,

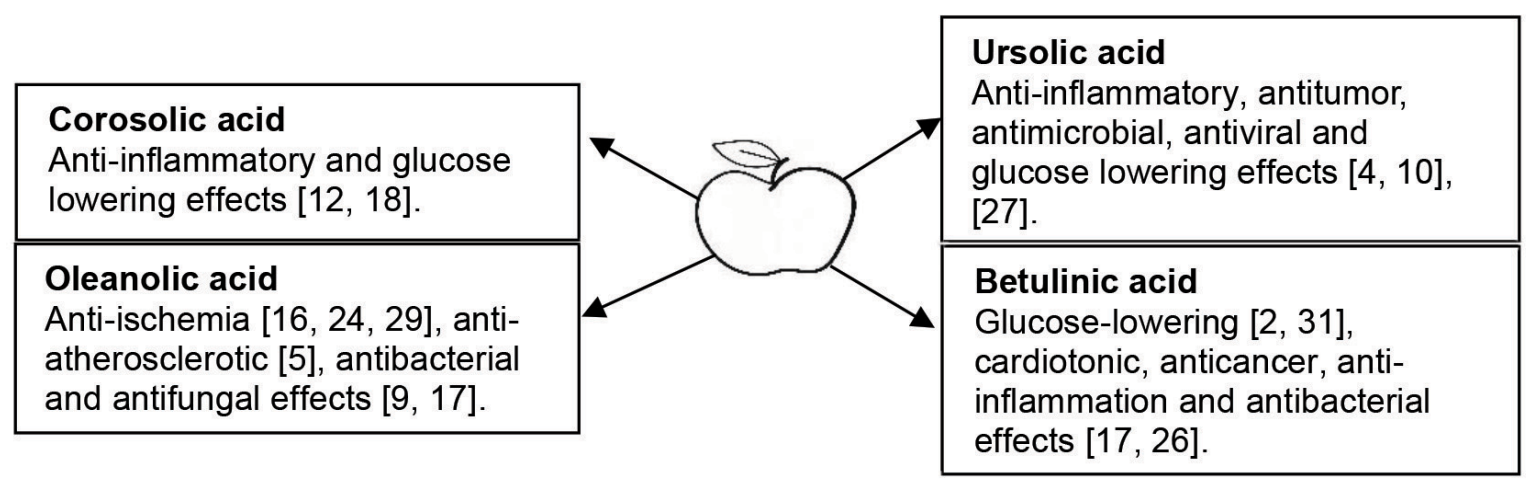

Fig. 1. Biological effects of triterpenic acids 
Table 1. Sampling dates and phenological growth stages of the apples

\begin{tabular}{|c|c|c|}
\hline Sampling dates & Day of the year & $\begin{array}{c}\text { Phenological growth } \\
\text { stages }\end{array}$ \\
\hline 17 June & 168 & \multirow{5}{*}{ Fruit development } \\
\hline 15 July & 196 & \\
\hline 12 August & 224 & \\
\hline 9 September & 252 & \\
\hline 16 September & 259 & \\
\hline 23 September & 266 & \multirow{5}{*}{ Fruit maturation } \\
\hline 30 September & 273 & \\
\hline 7 October & 281 & \\
\hline 14 October & 288 & \\
\hline 4 November & 308 & \\
\hline
\end{tabular}

DPPH (2,2-diphenyl-1-picrylhydrazyl) and sodium acetate were obtained from Scharlau (Sentmenat, Barcelona, Spain), TPTZ (2,4,6-tri(2-pyridyl)-s-triazine) was obtained from Carl Roth (Karlsruhe, Germany) and iron (III) ) chloride hexahydrate from Vaseline-Fabrik Rhenania (Bonn, Germany). Purified deionized water used in the tests was prepared with the Milli-Q ${ }^{\odot}$ (Millipore, Bedford, USA) water purification system.

\section{Preparation of samples}

Whole apples were immediately frozen in a freezer $\left(-35^{\circ} \mathrm{C}\right)$ with air circulation. Subsequently, these frozen samples were lyophilized with a ZIRBUS sublimator $3 \times 4 \times 5 / 20$ (ZIRBUS technology, Bad Grund, Germany) at a pressure of 0.01 mbar (condenser temperature: $-85^{\circ} \mathrm{C}$ ). The lyophilized samples were ground to fine powder by using a Retsch 200 mill electric grinder (Haan, Germany) [1]. Loss on drying before the analysis was determined by drying the apple lyophilisate in a laboratory drying oven to complete the evaporation of water and volatile compounds (temperature: $105^{\circ} \mathrm{C}$; the difference in weight between measurements: up to $0.01 \mathrm{~g}$ ) and by calculating the difference in raw material weight before and after drying [35]. The data were recalculated for the absolute dry lyophilisate weight. The prepared apple samples were stored in dark, tightly closed glass vessels.

\section{Extraction}

During the analysis, $1 \mathrm{~g}$ of lyophilizate powder (exact weight) was weighed, added to $10 \mathrm{~mL}$ of acetone, and extracted in a Sonorex Digital $10 \mathrm{P}$ ultrasonic bath (Bandelin Electronic $\mathrm{GmbH}$ \& Co. KG, Berlin, Germany) at room temperature for $10 \mathrm{~min}$. The conditions of the extraction were chosen based on the results of the tests for setting the extraction conditions. The obtained extract was filtered through a paper filter, and the residue on the filter was washed with acetone in a $10 \mathrm{~mL}$ flask until the exact volume was reached [1].

\section{Instruments}

The following devices were used in the study: a ZIRBUS $3 \times 4 \times 5 / 20$ lyophilizer (ZIRBUS technology, Bad Grund, Germany), a Retsch GM 200 mill electric grinder (Retsch GmbH, Han, Germany), a Bandelin Sanorex Digital 10P ultrasonic bath (Bandelin Electronic GmbH \& Co. KG, Berlin, Germany), a 2511 dry vacuum pump/compressor vacuum pump (Welch, Skokie, USA), a M550 UV-visible spectrophotometer (Spectronic CamSpec, Garford, UK), and a Waters 2695 Alliance chromatograph (Waters, Milford, USA) with a Waters 2998 PDA (Waters, Milford, USA) photodiode array detector.

\section{Instrumentation and chromatographic conditions}

A chromatograph equipped with a Waters 2998 PDA detector (Waters, Milford, USA) was used for HPLC analysis. Chromatographic separations were carried out by using an ACE $(5 \mu \mathrm{m}, \mathrm{C} 18$, $250 \times 4.6 \mathrm{~mm}$ i.d.) column. The column was operated at a constant temperature of $25^{\circ} \mathrm{C}$. The volume of the analysed extract was $10 \mu \mathrm{L}$. The flow rate was $1 \mathrm{~mL} / \mathrm{min}$. The mobile phase consisted of acetonitrile (solvent A) and water (solvent B). We applied isocratic elution, the eluent ratio being $88 \%$ (solvent $\mathrm{A}$ ) and $12 \%$ (solvent B). For the quantitative analysis, the calibration curve was obtained by injecting the known concentrations of different standard compounds. All the identified triterpenic compounds were quantified at $205 \mathrm{~nm}$ wavelength [1].

\section{Determination of antioxidant activity}

The $\mathrm{DPPH}^{\cdot}$ free radical scavenging assay was the following: $3 \mathrm{~mL}$ of $\mathrm{DPPH} \cdot$ solution were mixed with $100 \mu \mathrm{L}$ of the acetone extract of apple samples. A decrease in absorbance was measured at $\lambda=517 \mathrm{~nm}[32]$. The $\mathrm{ABTS}^{-+}$free radical scavenging 
assay was carried out in the following manner: $3 \mathrm{~mL}$ of $\mathrm{ABTS}^{\cdot+}$ solution were mixed with $100 \mu \mathrm{L}$ of the acetone extract of apple samples. A decrease in absorbance was measured at $\lambda=734 \mathrm{~nm}$ [32]. The procedure of the FRAP assay was the following: the FRAP solution included TPTZ $(0.01 \mathrm{M}$ dissolved in $0.04 \mathrm{M} \mathrm{HCl}), \mathrm{FeCl}_{3} \times 6 \mathrm{H}_{2} \mathrm{O}(0.02 \mathrm{M}$ in water) and an acetate buffer $(0.3 \mathrm{M}, \mathrm{pH} 3.6)$ (ratio 1:1:10). During the testing, $3 \mathrm{~mL}$ of a freshly prepared FRAP reagent were mixed with $100 \mu \mathrm{L}$ of the acetone extract of apple samples. An increase in absorbance was recorded at $\lambda=593 \mathrm{~nm}$ [15]. The CUPRAC assay was performed in the following manner: the CUPRAC solution included copper (II) chloride ( $0.01 \mathrm{M}$ in water), an ammonium acetate buffer solution $(0.001 \mathrm{M}, \mathrm{pH}=7)$ and neocuproine ( $0.0075 \mathrm{M}$ in ethanol) (ratio 1:1:1). During the testing, $3 \mathrm{~mL}$ of CUPRAC reagent were mixed with $100 \mu \mathrm{L}$ of the acetone extract of apple samples. An increase in absorbance was recorded at $\lambda=450 \mathrm{~nm}$ [23]. The calculation of the antioxidant activity of the acetone extract of apple samples was the following: the antioxidant activity of the extracts was calculated from the trolox calibration curve and expressed as a $\mu$ mol trolox equivalent (TE) per gram of the absolutely dry weight (DW). TE was calculated according to the formula $\mathrm{TE}=\mathrm{c} \times \mathrm{V} / \mathrm{m}\left(\mu \mathrm{mol} \mathrm{g} \mathrm{g}^{-1}\right)$, where $\mathrm{c}$ was the concentration of trolox established from the calibration curve (in $\mu \mathrm{M}$ ), $\mathrm{V}$ was the volume of the apple extract (in L), and $m$ was the weight (precise) of the lyophilized apple powder (in g).

\section{RESULTS AND DISCUSSION}

\section{Evaluation of triterpenic compounds in the apple samples}

Triterpenic compounds (betulinic acid, corosolic acid, oleanolic acid and ursolic acid) were identified in acetone extracts of the Ligol and Connel Red apple cultivars. In the apple samples of the Ligol and Connel Red cultivars, the highest total amounts of triterpenic compounds (respectively, $2.63 \pm 0.26 \mathrm{mg} / \mathrm{g}$ and $2.21 \pm 0.85 \mathrm{mg} / \mathrm{g}$ ) were detected at the beginning of the phenological stage of fruit development (on the 168th and the 252nd days of the year) (Fig. 2). In the samples of the Ligol and Connel Red apple cultivars, the lowest total amounts of triterpenic compounds (respectively, $1.72 \pm 0.28 \mathrm{mg} / \mathrm{g}$ and

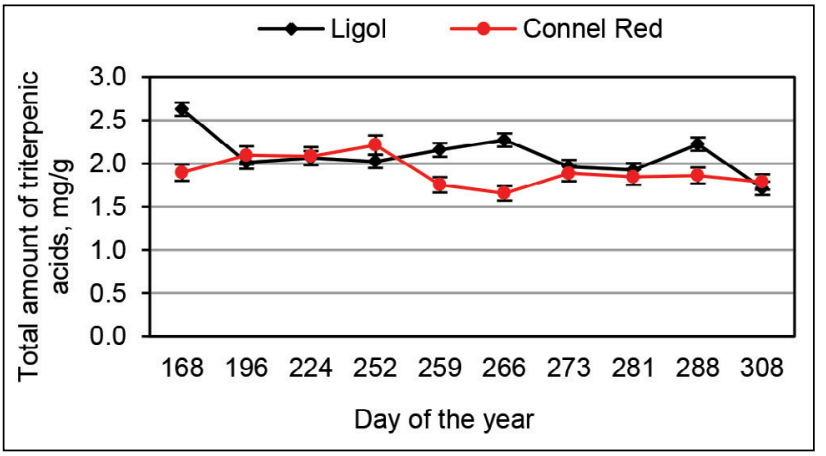

Fig. 2. Variation in the quantitative composition of the total amount of triterpenic acids during different phenological growth stages of the apples

$1.66 \pm 0.28 \mathrm{mg} / \mathrm{g}$ ) were detected during the phenological stage of fruit maturation (on the 308th and the 288th days of the year) (Fig. 2). The analysis using the HPLC method with gradient elution showed that the highest amount of total phenolic compounds $(20.97 \pm 0.74 \mathrm{mg} / \mathrm{g})$ was detected at the beginning of the fruit development period (on the 168th day of the year), and the lowest amount $(1.61 \pm 0.05 \mathrm{mg} / \mathrm{g})$ during the apple maturation period [21.

In this study, we evaluated the amounts of individual triterpenic compounds during the phenological stages of apple development and maturation. The analysis of the apple samples showed that the amounts of individual triterpenic compounds varied during different phenological growth stages of the fruit. These results confirm the data of other studies where the amounts of individual triterpenic compounds in apple samples varied [19].

Of all the identified and quantified triterpenic compounds, ursolic acid predominated in the studied apple samples. The highest amount of ursolic acid was detected at the beginning of the fruit development period (on the 168th and the 196th days of the year): in the apple samples of the Ligol cultivar, it was $2.13 \pm 0.17 \mathrm{mg} / \mathrm{g}$, and in the samples of the Connel Red cultivar $1.65 \pm 0.25 \mathrm{mg} / \mathrm{g}$ (Fig. 3). The lowest amount of ursolic acid was detected during the apple maturation period (on the 281st and the 266th days of the year): in the apple samples of the Ligol cultivar, it was $1.44 \pm 0.34 \mathrm{mg} / \mathrm{g}$, and in the samples of the Connel Red cultivar $1.28 \pm 0.22 \mathrm{mg} / \mathrm{g}$ (Fig. 3). A study by German researchers where the HPLC method with the gradient elution system was used 


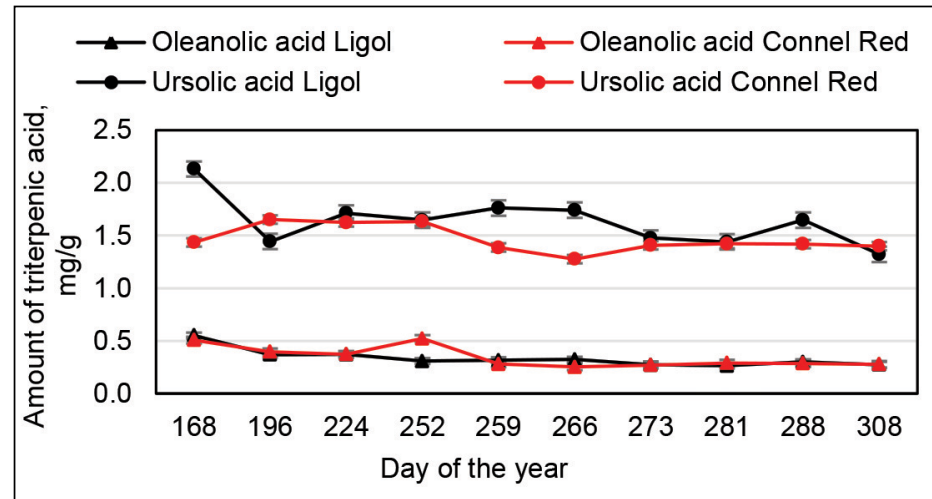

Fig. 3. Variation in the amounts of ursolic and oleanolic acids during different phenological growth stages of the apples

showed that the amount of ursolic acid in the apple samples varied from 0.80 to $1.43 \mathrm{~g} / 100 \mathrm{~g}$ [25]. Our results confirmed these data and revealed that the amount of ursolic acid in apple samples of $\mathrm{Li}^{-}$ gol and Connel Red cultivars grown in Lithuania was higher than that reported in the aforementioned study.

The highest amount of oleanolic acid was detected during the phenological stage of apple development (on the 168th and the 252nd days of the year): in the apple samples of the Ligol cultivar, it was $0.55 \pm 0.09 \mathrm{mg} / \mathrm{g}$, and in the samples of the Connel Red cultivar $0.52 \pm 0.42 \mathrm{mg} / \mathrm{g}$ (Fig. 3). The lowest amount of oleanolic acid was detected during the phenological stage of apple maturation (on the 308th and the 266th days of the year): in the apple samples of the Ligol cultivar, it was $0.27 \pm 0.05 \mathrm{mg} / \mathrm{g}$, and in the samples of the Connel Red cultivar $0.25 \pm 0.05 \mathrm{mg} / \mathrm{g}$ (Fig. 3). The results of this study are in line with those reported in a study conducted by German and French researchers, where the content of oleanolic acid in the apple ranged from 0.16 to $1.0 \mathrm{~g} / 100 \mathrm{~g}$ [25, 30]. Such factors as the geographical region and climatic-meteorological and cultivation conditions could have influenced these quantitative differences.

The variation in the amount of corosolic acid detected in the apple samples throughout the phenological growth stages of the fruit differed from that of the previously discussed ursolic and oleanolic acids. The highest amount of corosolic acid was detected at the end of the phenological stage of apple maturation (on the 288th and the 308th days of the year): in the apple samples of the Ligol cultivar, it was $0.30 \pm 0.09 \mathrm{mg} / \mathrm{g}$, and in the samples of the Connel Red cultivar $0.12 \pm 0.2 \mathrm{mg} / \mathrm{g}$ (Fig. 4). These results differed from those described previously, where the highest amounts of ursolic and oleanolic acids were detected at the beginning of the phenological stage of apple development.

The amount of betulinic acid was the lowest of all the identified and quantified triterpenic compounds detected in the apple samples.

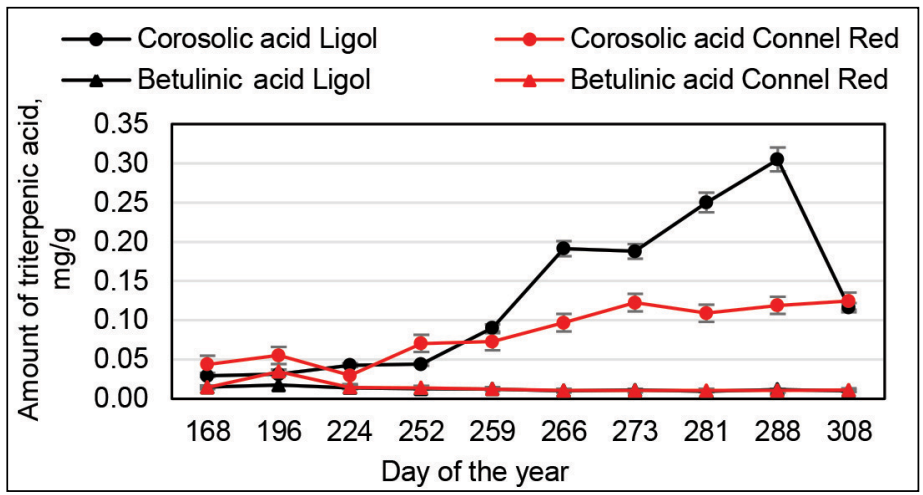

Fig. 4. Variation in the amounts of corosolic and betulinic acids during different phenological growth stages of the apples 
The highest amount of betulinic acid was detected at the beginning of the phenological stage of apple maturation (on the 196th day of the year): in the apple samples of the Connel Red cultivar, it was $0.30 \pm 0.09 \mathrm{mg} / \mathrm{g}$, and in the samples of the Ligol cultivar $0.02 \pm 0.001 \mathrm{mg} / \mathrm{g}$ (Fig. A). As the apples were developing and maturing, the amount of betulinic acid was decreasing.

The HPLC analysis of acetone extracts obtained from the apples revealed that ursolic acid was the most abundant compound in the samples investigated. Its amounts were considerably higher than those of other triterpenic acids, and were highest at the beginning of the phenological development stage of the fruit. The results of the HPLC analysis showed that the highest amount of triterpenic acids was accumulated at the beginning of the phenological development stage of the apples. According to the available data, apples are a valuable natural source of triterpenic acids. This encourages further research on this plant as raw material that could be used in pharmacy.

\section{Evaluation of antioxidant activity in the apple extracts}

Herbal extracts are multi-component matrices with antioxidant activity determined by a set of reactions with different mechanisms, and thus antioxidant activity cannot be evaluated by a single method [22]. For these reasons, the use of at least two different methods is recommended for the evaluation of antioxidant activity in herbal extracts [22]. In order to thoroughly evaluate the antioxidant effect of the acetone extracts of apples, different antioxidant capacity assays (DPPH, ABTS, CUPRAC and FRAP) were selected. Anti- radical DPPH and ABTS methods explain the potency of antioxidants to bind free radicals [20, 22]. $\mathrm{DPPH}^{*}$ is a free radical soluble in organic solvents, which limits the evaluation of antiradical activity in hydrophilic compounds [21, 32]. ABTS ${ }^{++}$free radical is a cation soluble in water and organic solvents, which allows for evaluating the antiradical activity of hydrophilic and lipophilic compounds in weakly alkaline conditions $(\mathrm{pH}=7.4)[12,32]$. The CUPRAC method evaluates the reductive activity by measuring the antioxidant power to reduce $\mathrm{Cu}(\mathrm{II})$ to $\mathrm{Cu}(\mathrm{I})$ at $\mathrm{pH}=7.0$ [23]. The FRAP method aids in evaluating the reductive activity by assessing the reduction of $\mathrm{Fe}$ (III) to $\mathrm{Fe}$ (II) in acidic conditions $(\mathrm{pH}=3.6)$ [14, 15]. In order to find relationships between the antioxidant activity and the amount of triterpenic compounds in these extracts, the Pearson correlation coefficient was calculated [34].

The results of the study showed that the strongest antiradical effects by binding DPPH ${ }^{*}$ free radicals in acetone extracts of the Ligol $(11.23 \pm 0.43 \mu \mathrm{mol} \mathrm{TE} / \mathrm{g})$ apple cultivar and in acetone extracts of the Connel Red $(10.63 \pm 0.58 \mu \mathrm{mol}$ $\mathrm{TE} / \mathrm{g}$ ) apple cultivar were observed at the beginning of the phenological fruit development stage (on the 168th day of the year) (Fig. 5). As the apples were developing and maturing, the antioxidant activity was decreasing. The weakest antiradical effects by binding $\mathrm{DPPH}$ - free radicals in acetone extracts of the Ligol $(2.47 \pm 0.38 \mu \mathrm{mol} \mathrm{TE} / \mathrm{g})$ apple cultivar and in acetone extracts of the Connel Red $(2.92 \pm 0.37 \mu \mathrm{mol} \mathrm{TE} / \mathrm{g})$ apple cultivar were observed during the phenological stages of apple maturation (on the 288th and the 273rd days of the year) (Fig. 5). Antiradical activity determined

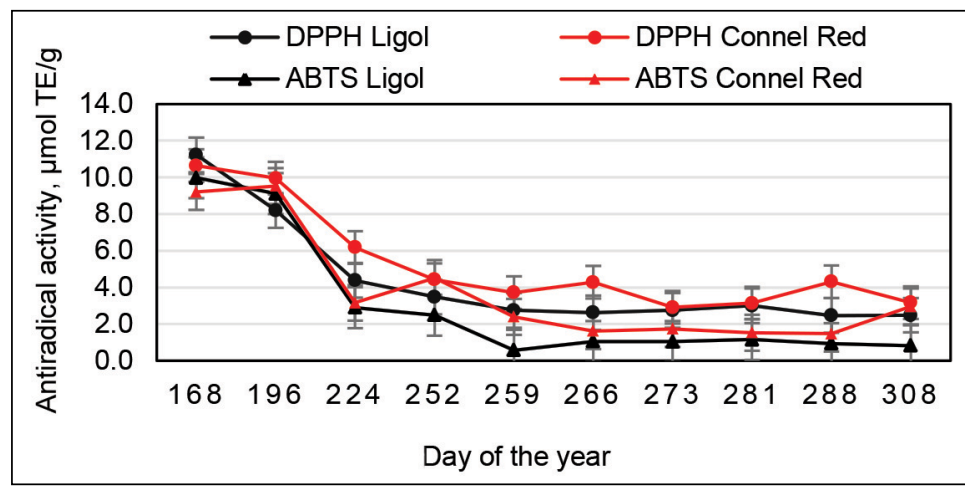

Fig. 5. Antiradical activity of the apple sample extracts evaluated via DPPH and $A B T S$ free radical scavenging assays during different phenological growth stages 
by the DPPH method had a moderate positive correlation with the amounts of the identified betulinic, corosolic and ursolic acids $(r=0.364-0.592)$ (Table 2). Oleanolic acid had a strong correlation with the antiradical effect detected via DPPH $(r=0.778)$ (Table 2). In a previous study, the researchers observed a similar antiradical activity by binding $\mathrm{DPPH} \cdot$ free radicals in ethanol extracts of apples [21]. The study showed that the strongest antiradical activity by binding $\mathrm{DPPH} \cdot$ free radicals $(81.02 \mu \mathrm{mol} \mathrm{TE} / \mathrm{g})$ was observed at the beginning of the apple development stage (on the 168th day of the year). As apples were maturing, the antioxidant activity was decreasing [21.

The strongest antiradical effects by binding $\mathrm{ABTS}^{\cdot+}$ free radicals in acetone extracts of the Ligol $(9.97 \pm 0.15 \mu \mathrm{mol} \mathrm{TE} / \mathrm{g})$ apple cultivar and in the acetone extracts of the Connel Red $(9.53 \pm 0.53 \mu \mathrm{mol} \mathrm{TE} / \mathrm{g})$ apple cultivar were observed at the beginning of the fruit development stage (on the 168th and the 196th days of the year) (Fig. 5). The weakest antiradical effects by binding $\mathrm{ABTS}^{*+}$ free radicals in acetone extracts of the Ligol $(0.58 \pm 0.33 \mu \mathrm{mol} \mathrm{TE} / \mathrm{g})$ apple cultivar and in acetone extracts of the Connel Red $(1.48 \pm 0.27 \mu \mathrm{mol}$ $\mathrm{TE} / \mathrm{g}$ ) apple cultivar were observed at the end of the apple development period (on the 259th day of the year) and during the fruit maturation period (on the 288th day of the year) (Fig. 5). Antioxidant activity established by the ABTS method had a strong correlation $(r=0.784)$ with the amount of oleanolic acid, and a moderate correlation $(r=0.337-0.594)$ with the amounts of the other identified triterpenic acids was observed (Table 2). Chen et al. performed a similar study to evaluate the antiradical activity of apple extracts by assessing the binding of $\mathrm{ABTS}^{*+}$ free radicals.
The results obtained in their study confirmed our research data indicating that the strongest antiradical activity by binding $\mathrm{ABTS}^{\bullet+}$ free radicals was observed at the beginning of the phenological stage of apple development, and the weakest one during the fruit maturation stage [11].

In the CUPRAC assays, the strongest reduction effects in acetone extracts of the $\mathrm{Li}^{-}$ gol $(38.27 \pm 2.77 \mu \mathrm{mol} \mathrm{TE} / \mathrm{g})$ apple cultivar and in acetone extracts of the Connel Red $(37.00 \pm 3.60 \mu \mathrm{mol} \mathrm{TE} / \mathrm{g})$ apple cultivar were observed at the beginning of the phenological stage of apple development (on the 168th and the 196th days of the year) (Fig. 6). As apples were developing and maturing, the reduction activity was decreasing. The weakest reduction effects evaluated via the CUPRAC assays in acetone extracts of the Ligol $(2.85 \pm 1.23 \mu \mathrm{mol} \mathrm{TE} / \mathrm{g})$ apple cultivar and acetone extracts of the Connel Red $(3.42 \pm 1.20 \mu \mathrm{mol} \mathrm{TE} / \mathrm{g})$ apple cultivar were observed in the middle of the phenological stage of apple maturation (on the 281st and the 273rd days of the year) (Fig. 6). The content of ursolic, corosolic and betulinic acids had a moderate correlation ( $r=0.393-0.606)$ with reductive activity determined by the CUPRAC method (Table 2). Oleanolic acid had a strong correlation $(r=0.720)$ with reductive activity established by the CUPRAC assay (Table 2).

The strongest reduction effects evaluated by the FRAP assay in acetone extracts of the Ligol $(27.61 \pm 2.88 \mu \mathrm{mol} \mathrm{TE} / \mathrm{g})$ apple cultivar and in acetone extracts of the Connel Red $(23.67 \pm 1.79 \mu \mathrm{mol} \mathrm{TE} / \mathrm{g})$ apple cultivar were observed at the beginning of the apple development period (on the 168th and the 196th days of the year) (Fig. 6). The weakest reduction effects

Table 2. Amount of triterpenic acids ( $\mathrm{mg} / \mathrm{g}$ ) and antioxidant activity in apple extracts in vitro $(\mu \mathrm{mol} \mathrm{TE} / \mathrm{g})$, Pearson correlation coefficients

\begin{tabular}{c|c|c|c|c}
\hline $\begin{array}{c}\text { Antioxidant activity, } \boldsymbol{\mu m o l ~ T E / g} \\
\text { Amount of triterpenic acids, } \mathbf{m g} / \mathbf{g}\end{array}$ & DPPH & ABTS & CUPRAC & FRAP \\
\hline Betulinic acid & 0.515 & 0.594 & 0.606 & 0.593 \\
\hline Corosolic acid & 0.592 & 0.585 & 0.474 & 0.447 \\
\hline Oleanolic acid & 0.778 & 0.784 & 0.720 & 0.632 \\
\hline Ursolic acid & 0.364 & 0.337 & 0.352 & 0.388 \\
\hline Total amount & 0.383 & 0.387 & 0.393 & 0.429 \\
\hline
\end{tabular}

$0<|r| \leq 0.3$ is a weak correlation; $0.3<|r| \leq 0.7$ is a moderate correlation; $0.7<|r| \leq 1$ is a strong correlation [34]. 


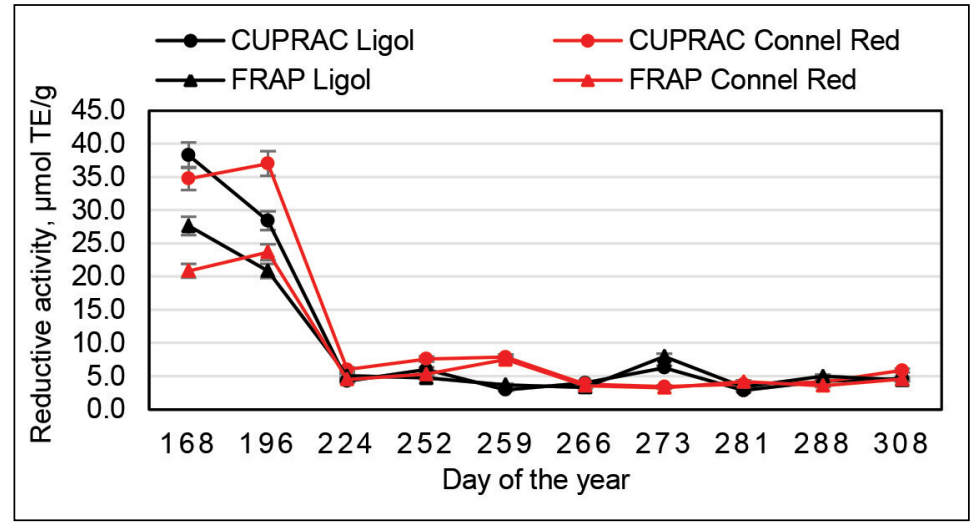

Fig. 6. Reduction activity of the apple sample extracts evaluated via CUPRAC and FRAP assays during different phenological growth stages

evaluated by the FRAP assay in acetone extracts of the Ligol $(3.33 \pm 0.54 \mu \mathrm{mol} \mathrm{TE} / \mathrm{g})$ apple cultivar and in acetone extracts of the Connel Red (3.26 $\pm 0.29 \mu \mathrm{mol} \mathrm{TE} / \mathrm{g})$ apple cultivar were detected in the middle of the phenological stage of apple maturation (on the 266th and the 273rd days of the year) (Fig. 6). Reductive activity evaluated by the FRAP assay had a moderate correlation $(r=0.388-0.632)$ with the amount of the identified triterpenic acids (Table 2). Scientists from Korea performed an evaluation of the reduction activity by the FRAP assay and found that the reduction activity was strongest $(16.75 \pm 0.29 \mu \mathrm{mol} \mathrm{TE} / \mathrm{g})$ at the beginning of the phenological stage of apple development, and the weakest $(0.77 \pm 0.03 \mu \mathrm{mol} \mathrm{TE} / \mathrm{g})$ during the phenological stage of apple maturation [14. The results of our study confirmed these data and revealed that antiradical activity of the samples of apple cultivars grown in Lithuania was stronger than those published in the aforementioned article.

In order to determine the relationship between the antioxidant activity of the acetone extracts of apples assessed by DPPH, ABTS, CUPRAC and FRAP assays and the total amount of triterpenic acids in these extracts, a correlation analysis was carried out. There was a moderate positive correlation of the contents of ursolic, corosolic and betulinic acids as well as the total amount of triterpenic acids with the antioxidant activity assessed by all the methods $(r=0.337-0.632)$. The strongest positive correlation was observed between the amount of oleanolic acid and the antioxidant activity assessed by the DPPH, ABTS and CUPRAC methods (respectively, $r=0.778, r=0.784$ and $r=0.720)$.

\section{CONCLUSIONS}

The HPLC-based analysis was applied for the detection of triterpenic compounds in apple samples during different phenological stages of the fruit. The highest total amount of triterpenic acids $(2.63 \pm 0.26 \mathrm{mg} / \mathrm{g})$ was detected in the Ligol apple cultivar at the beginning of the phenological stage of fruit development (on the 168th day of the year), and the lowest amount $(1.66 \pm 0.28 \mathrm{mg} / \mathrm{g})$ in the Connel Red apple cultivar during the phenological stage of fruit maturation (on the 288th day of the year). The distribution of the four analysed triterpenic acids was evaluated in the tested whole apple extracts. Throughout the phenological stages of the fruit, the quantitative composition of triterpenic acids could be arranged in the following ascending order: betulinic acid $<$ corosolic acid $<$ oleanolic acid $<$ ursolic acid.

The in vitro evaluation of antioxidant activity was performed. The strongest antiradical $\left(\mathrm{TE}_{\mathrm{DPPH}}=11.23 \pm 0.43 \mu \mathrm{mol} \mathrm{TE} / \mathrm{g}\right.$ and $\mathrm{TE}_{\mathrm{ABTS}}=$ $9.97 \pm 0.15 \mu \mathrm{mol} \mathrm{TE} / \mathrm{g}$ ) activity was observed in the extracts of apple samples collected at the beginning of the phenological stage of fruit development (on the 168th day of the year). The strongest reductive $\left(\mathrm{TE}_{\text {CUPRAC }}=38.27 \pm 2.77 \mu \mathrm{mol} \mathrm{TE} / \mathrm{g}\right.$ and $\mathrm{TE}_{\mathrm{FRAP}}=27.61 \pm 2.88 \mu \mathrm{mol} \mathrm{TE} / \mathrm{g}$ ) activity was found during the phenological stage of apple development (on the 168th day of the year). Antioxidant activity established by DPPH, ABTS and CUPRAC methods had a stronger correlation with the amount of oleanolic acid (respectively, $r=0.778, r=0.784$ and $r=0.720)$, compared to the other identified triterpenic compounds. 
The results obtained in this study encourage further research on the phytochemical composition and biological activity of apple extracts. The evaluation of the antioxidant activity of individual triterpenic acids in vitro and in vivo would help to determine the potential of apples as raw material in medical practice as well as in the development and production of dietary supplements and cosmetic preparations rich in biologically active compounds.

Received 24 January 2020 Accepted 14 February 2020

\section{References}

1. A. Butkevičiūtè, M. Liaudanskas, D. Kviklys, et al., Int. J. Food Prop., 21, 1716 (2018).

2. A. K. Hamida, A. Kama, K. H. Wonga, et al., Curr. Med. Chem., 20, 908 (2013).

3. B. Dinda, S. Debnath, B. C. Mohanta, Y. Harigaya, Chem. Biodivers., 7, 2327 (2010).

4. C. Brendolise, Y. K. Yauk, E. D. Eberhard, et al., FEBS, 278, 2485 (2011).

5. C. M. Andre, J. M. Greenwood, E. G. Walker, et al., J. Agric. Food Chem., 60, 10546 (2012).

6. D. Camer, Y. Yu, A. Szabo, X. F. Huang, Mol. Nutr. Food Res., 58, 1750 (2014).

7. D. Klimavičius, D. Klimavičienė, N. Jurkšaitienė, Mokslo darbai, 8, 13 (2017).

8. D. Kviklys, M. Liaudanskas, V. Janulis, et al., Plant Soil Environ., 60, 234 (2014).

9. D. A. Hyson, Adv. Nutr., 2, 408 (2011).

10. D. B. Cortina, A. Macià, I. Iglesias, M. P. Romero, M. J. Motilva, J. Agric. Food Chem., 5, 1684 (2016).

11. F. Chen, F. Li, L. Lu, X. Zhang, X. Xu, D. Li, Int. J. Food Sci. Tech., 49, 1680 (2014).

12. G. Sivakumar, D. R. Vail, V. Nair, F. M. Bolivar, J. O. Lay Jr., Biotechnol. J., 4, 1704 (2009).

13. G. Verardo, A. Gorassini, D. Ricci, D. Fraternale, Phytochem. Anal., 28, 5 (2016).

14. H. Z. Zheng, Y. Kim, S. K. Chung, Food Chem., 131, 106 (2012).
15. I. F. F. Benzie, J. J. Strain, Method. Enzymol., 299, 15 (1998).

16. Y. Allouche, G. Beltrán, J. J. Gaforio, M. Uceda, M. D. Mesa, Food Chem. Toxico., 48, 2885 (2010).

17. J. W. Jeong, J. J. Shim, I. D. Choi, et al., J. Med. Food, 18, 1380 (2015).

18. J. M. R. Patlolla, C. V. Rao, Curr. Pharm. Biotechno., 13, 147 (2012).

19. L. Yanrong, Acta. Uni. Agric. Suec. Agrar., 5, 13 (2016).

20. L. Raudonè, R. Raudonis, M. Liaudanskas, V. Janulis, P. Viskelis, Sci. Hortic., 216, 186 (2017).

21. M. Liaudanskas, R. Brunevičiūtè, K. Gaivelytè, et al., IJBCRR, 14, 1 (2016).

22. M. Liaudanskas, K. Zymone, J. Viskelis, D. Kviklys, P. Viskelis, J. V. Janulis, Chem. Nat. Comp., 54, 348 (2018).

23. M. Özyürek, K. GüçLü, E. Tütem, et al., Anal. Methods, 3, 2439 (2011).

24. N. Han, M. Bakovic, J. Bioanal. Biomed., 12, 3 (2015).

25. S. Jäger, H. Trojan, T. Kopp, M. N. Laszczyk, A Scheffler, Molecules, 14, 20161 (2009).

26. S. T. Cargnin, S. B. Gnoatto, Food Chem., 220, 477 (2017).

27. T. A. Padua, B. S. S. C. Abreu, T. E. M. M. Costa, et al., Arch. Pharm. Res., 37, 1487 (2014).

28. V. Nour, I. Trandafir, M. E. Ionica, Not. Bot. Hort. Agrobot. Cluj., 38, 228 (2010).

29. V. R. Netala, S. B. Ghosh, P. Bobbu, D. Anitha, V. Tartte, Int. J. Pharm. Pharm. Sci., 7, 24 (2015).

30. Z. Jemmali, A. Chartiern, C. Dufresne, C. Elfakir, Talanta, 147, 35 (2016).

31. Q. Q. He, L. Yang, J. Y. Zhang, J. N. Ma, C. M. Ma, J. Food Sci., 79, 970 (2014).

32. W. Brand-Williams, M. E. Cuvelier, C. Berset, Food Sci. Technol., 28, 25 (1995).

33. Food and Agriculture Organization of the United Nations Statistics Division. FAOSTAT, 2019 http:// faostat3.fao.org/browse/Q/QC/E.

34. V. Cekanavičius, Taikomoji regresine analizé socialiniuose tyrimuose, p. 124, Vilnius (2011).

35. European Pharmacopoeia, 9th edn., p. 51 (2017). 
Aurita Butkevičiūtè, Rima Urbštaitè,

Mindaugas Liaudanskas, Darius Kviklys,

Jonas Viškelis, Valdimaras Janulis

LIETUVOS KLIMATO SĄLYGOMIS

AUGINAMŲ OBELŲ VEISLIŲ VAISIŲ

EKSTRAKTŲ TRITERPENŲ KOKYBINĖS

IR KIEKYBINĖS SUDE்TIES IৃVIROVE்S BEI

ANTIOKSIDANTINIO POVEIKIO TYRIMAS

AUGIMO IR NOKIMO TARPSNIAIS

Santrauka

Naminių obelų (Malus domestica Borkh.) vaisiuose nustatyti fenoliniai glikozidai, triterpeninès rūgštys ir kiti biologiškai aktyvūs junginiai. Obuoliai plačiai vartojami kaip maisto produktas ir yra svarbūs dèl juose esančiu biologiškai aktyvių junginių, lemiančiu vaisių ir iš jų pagamintų produktų teigiamą poveikị žmogaus organizmui. Todèl būtina tirti vaisių kokybinę ir kiekybinę biologiškai aktyvių junginių sudetį.

Straipsnyje pateikiami tyrimų duomenys apie triterpeninių rūgščių kiekybinès sudèties ịvairovę ir jos pokyčius obuolių augimo ir nokimo laikotarpiais. Taikytas efektyviosios skysčių chromatografijos analizès metodas. Didžiausias suminis triterpeninių rūgščių kiekis nustatytas obuolių augimo fenologinio tarpsnio pradžioje. Obuoliams nokstant, triterpeninių rūgščių kiekis mažèja nuo $2,63 \pm 0,26 \mathrm{mg} / \mathrm{g}$ iki $1,66 \pm 0,28 \mathrm{mg} / \mathrm{g}$. Atliekant tyrimą identifikuoti ir kiekybiškai ìvertinti keturi triterpeniniai junginiai, kuriuos pagal kiekybinę sudèti galima išdèstyti mažèjimo tvarka: betulino rūgštis $<$ korosolio rūgštis $<$ oleanolo rūgštis $<$ ursolo rūgštis.

Kad augaliniai ekstraktai būtų sèkmingai naudojami medicinos praktikoje, svarbu atlikti jų poveikio tyrimus in vitro ir in vivo. Antioksidantai iqvairiais veikimo mechanizmais geba neutralizuoti žalingas reaktyvias deguonies ir azoto formas, jų vartojimas stiprina antioksidantines apsaugos sistemas. Skirtingais fenologiniais tarpsniais ịvertinome obuolių ekstraktų antioksidantini aktyvumą in vitro. Stipriausias antiradikalinis ir redukcinis aktyvumas nustatytas obuolių augimo fenologinio tarpsnio pradžioje. Ivertinta obuolių ekstraktų individualių triterpeninių rūgščių kiekio ir antioksidantinio aktyvumo, nustatyto DPPH, ABTS, CUPRAC ir FRAP metodais, koreliacija. Irrodyta stipri koreliacija tarp oleanolo rūgšties kiekio ir antioksidantinio aktyvumo, nustatyto DPPH, ABTS ir CUPRAC metodais (atitinkamai: $r=0,778, r=0,784$ ir $r=0,720$ ). 